\title{
Impact of effluent disposal pit on groundwater quality at Sabriya oil field
}

\author{
M. Al-Senafy, A. Mukhopadhyay, A. Al-Khalid, H. Bhandary, \\ K. Al-Fahad \& A. Bushehri \\ Hydrology Department, Water Resources Division, \\ Kuwait Institute for Scientific Research, Kuwait
}

\begin{abstract}
Based on an earlier surface resistivity survey and KOC recognition of the threat imposed by the discharge pits upon the groundwater quality in the areas of its operation, this study was carried out to determine any potential source of contamination and to construct a groundwater quality monitoring network around the disposal pit located at Sabriya oil fields in northern Kuwait. One production well and three monitoring wells were designed, constructed, and logged. Water samples from the disposal pit and four groundwater samples from the newly drilled wells were analyzed for physical, chemical, biological and isotopic components. The results of the pumping tests, groundwater levels, and chemical analysis were incorporated in a visual MODFLOW numerical model. It was concluded that the brine water disposed in the Sabriya pit along with the pollutants carried in it had infiltrated and raised both the water table and the levels of salinity and other pollutants in the groundwater. To protect the fresh and brackish groundwater reserves of this area, which is of strategic importance to Kuwait, it has been recommended that the disposal of the oil field brines and the associated pollutants in the discharge pits should be discontinued immediately and other methods of disposal should be considered.
\end{abstract}

Keywords: contamination, levels, wells, pumping test, modelling.

\section{Introduction}

Disposal of produced water which contains several types of wastes that are associated with oil production operations had never been a problem for $40 \mathrm{yrs}$ for the petroleum industry in Kuwait. The large available desert areas surrounding 
the oil fields helped to ease the disposal process [1]. In 1988, it was first noticed that the produced water was increasing incrementally. It increased to about 250,000 barrels/d, making it impossible to rely on sunlight to complete the process of evaporation at the required rate [2-4]. Since that time, the Kuwait Oil Company (KOC) began to move toward an appropriate solution that took into consideration the required discharge, the environmental standards, and the feasibility of the proposed method [1].

The pollutants on the ground surface in the study area of the disposal pit could reach the water table and contaminate the unconfined aquifer (Kuwait Group) by the direct infiltration of pollutants from the pit, infiltration of rainfall that carry these pollutants leached from the surface and infiltration of disposed saline water. In fact, many such contaminations had been recorded in many of the major oil producing areas of the world [5-10].

Although there are many potential contaminants, some pose much more of a threat to groundwater than others. In this study, the potential contaminants could include one of the most threatening contaminants, that is, petroleum products in addition to the highly saline water. Moreover, the studied disposal pit is unlined and located in the close proximity of the sensitive fresh groundwater aquifers in Raudhatain and Umm Al-Aish areas. These fresh groundwater aquifers are unique in that, they provide the only source of natural groundwater with potable water quality. Pollution of this limited resource from the effluent pits is therefore an act of grave consequence to Kuwait. For this reason, the assessment of the extent of the groundwater pollution from the disposal pit is very important. The main objective of this study was to investigate the potential adverse impacts of effluent disposal pit on the groundwater quality at Sabriya oil fields of northern Kuwait and to recommend the necessary measures to prevent and remediate such adverse effects under oil exploration and disposal scenarios.

\section{Methodology}

\subsection{Groundwater well installation}

Based on a former surface geophysical survey and the available information, locations for one production well and three monitoring wells, $113 \mathrm{~mm}$ in diameter and 30-50 m deep, were selected and the wells were drilled, installed and developed in order to delineate the quality and the potential contaminants in the groundwater. Fig 1 presents the locations of the wells around Sabriya disposal pit in the study area. The final design of the installed monitoring and pumping wells is presented in table 1 .

\subsection{Soil sampling}

A total of about 205 drill cutting samples of $500 \mathrm{~g}$ were collected during drilling at $1-\mathrm{m}$ intervals in the 4 drilled wells. The samples were megascopically examined on-site, and further description was made in the laboratory to construct the conceptual lithological model of the study area. 
Table 1: $\quad$ Design of the installed pumping and monitoring wells in study area.

\begin{tabular}{|l|l|l|l|l|}
\hline Well No. & $\begin{array}{l}\text { Total } \\
\text { Depth }(\mathrm{m})\end{array}$ & $\begin{array}{l}\text { Casing Screen } \\
\text { Diameter }\end{array}$ & $\begin{array}{l}\text { Screen } \\
\text { Interval }(\mathrm{m})\end{array}$ & $\begin{array}{l}\text { Groundwater } \\
\text { Depth }(\mathrm{m})\end{array}$ \\
\hline DP-09 & 55 & 200 & $25-50$ & 34.00 \\
\hline DP-10 & 50 & 100 & $25-45$ & 18.00 \\
\hline DP-11 & 50 & 100 & $25-45$ & 13.90 \\
\hline DP-12 & 50 & 100 & $25-45$ & 19.60 \\
\hline
\end{tabular}

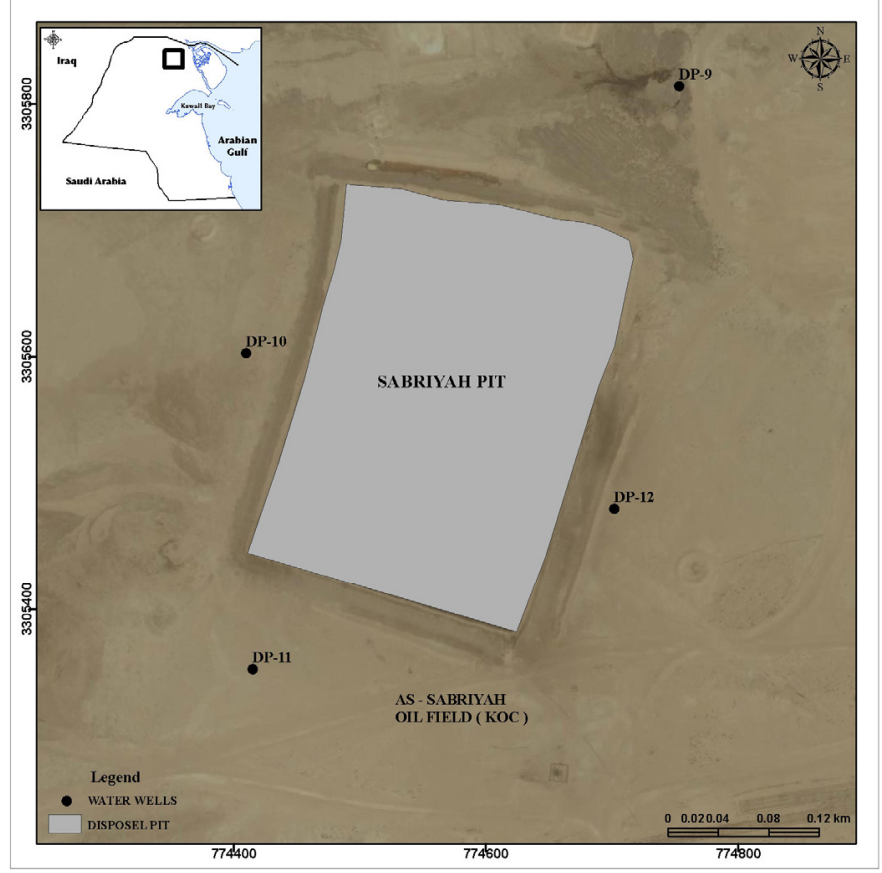

Figure 1: $\quad$ Location of wells at Sabriya pit.

\subsection{Groundwater sampling}

Following the completion of well development and measurement and recording of water level, an electric submersible pump was used for purging the screened interval of the four pumping and monitoring wells that were drilled at Sabriya disposal pits to enable the collection of representative groundwater samples. Groundwater samples were collected according to the United States Environmental Protection Agency sampling guidelines [11]. In addition to sampling the drilled wells, more samples were collected from the existing groundwater wells in the vicinity of the study area. The analyses results for these wells will help in delineating the extent of the impact of the disposal pit. 


\subsection{Pumping tests}

Pumping and recovery tests were performed. Well DP-09 was the pumping well and $100 \mathrm{gal} / \mathrm{min}$ was the discharge rate for $16 \mathrm{~h}$. Three wells, namely; DP-10, DP-11, and DP-12 were used as observation wells during the pumping and the recovery tests, fig. 1 . The test was terminated after $16 \mathrm{~h}$ due to the rise of water level as a result of filling the pit by effluent disposal.

\subsection{Laboratory analyses}

The collected groundwater samples and the effluent pit samples were analyzed for a wide range of parameters. The standard USEPA methods were adopted to analyze water parameters in the laboratory. Samples were also analyzed of stable isotopes which are Oxygen-18 and Deuterium.

\subsection{Numerical modelling}

The Visual MODFLOW version 2010.1 software of Schlumberger Water Services was used for the numerical modeling of flow and transport of infiltrated water from the pit within the aquifers of the study area. The USGS SEAWAT 2000 engine [12] is included in this software, allowing modeling of variable density flow such as seawater intrusion modeling problems. SEAWAT combines a flow code (MODFLOW) with a solute-transport code (MT3DMS) to form a single program that solves the coupled flow and solute-transport equations. It formulates flow equations using mass conservation instead of volume conservation.

\section{Results and discussion}

\subsection{Local aquifer and lithology}

The lithological descriptions at the disposal pit study area are presented in table 2 .

Table 2: $\quad$ Lithological section at Sabriya pit study area.

\begin{tabular}{|l|l|}
\hline Depth $(\mathrm{m})$ & Lithology \\
\hline $1-3$ & Gravely Sand \\
\hline $3-15$ & Sandy Gravel \\
\hline $15-19$ & Gravely Sand \\
\hline $19-27$ & Clayey Sand \\
\hline $27-31$ & Calcareous Clayey Sand \\
\hline $31-41$ & Calcareous Silty Sand \\
\hline $41-49$ & Calcareous Sand Stone \\
\hline $49-55$ & Calcareous Gravely Sand \\
\hline
\end{tabular}




\subsection{Groundwater quality}

Sabriya pit is within two kilometers of the fresh groundwater body located under the Umm Al-Aish depression; and hence this resource is vulnerable to contamination from the pit. Fortunately, this pit is located down gradient of the freshwater body. As a result, unless there is a reversal in hydraulic gradient either due to high volume sustained production from the Umm Al-Aish freshwater field or due to massive discharge through the pit or both, the possibility of harm to the freshwater resource of the area from the pit is not that high. The water levels measured in the monitoring wells around the pit however show that the recharge mound below the pit has reached almost $27 \mathrm{~m}$ above the mean sea level and the relatively high gradient created by the mound should have caused spreading of the pollutants away from the pit. The brackish water resource (TDS 4000-8000 mg/l) in the vicinity has been compromised due to the leakage from the pit.

The groundwater in this study area was found to be highly saline (brine) in nature, and the salinity to be the same as that of pit water, showing clear contamination. The TDS ranged from 88860 to $176110 \mathrm{mg} / \mathrm{l}$ with an average concentration of $146152 \mathrm{mg} / \mathrm{l}$, indicating brine water quality, whereas pit water salinity found was $165400 \mathrm{mg} / \mathrm{l}$. Total petroleum hydrocarbon was detected in high concentrations ranging from 1.9 to $5 \mathrm{mg} / \mathrm{l}$ with an average value of $3.77 \mathrm{mg} / \mathrm{l}$, whereas $\mathrm{TPH}$ in pit water found was $6.04 \mathrm{mg} / \mathrm{l}$. The laboratory analysis of this groundwater confirmed the groundwater contamination from the disposed pit water, as the quality of pit water and groundwater matched clearly.

\subsection{Numerical modelling of Sabriya pit}

During the calibration runs, it was realized that to obtain a good match of observed water level and water quality data with the simulated results, no uniform infiltration rates from different parts of the pit had to be assumed. These variations could have possibly been related to the conditions of the floor of the pit and the extent of deposition of heavy oil and sludge on the bottom.

Six cycles of discharge (and hence, groundwater recharge incidents) have been assumed within the first year of the simulation run in order to investigate the effects of multiple, frequent discharge to the disposal pits on the groundwater level and quality.

The produced plots of calculated and observed heads against time indicated that, in general, the observed heads matched very well with the general trend of the calculated heads in the monitoring wells. The plots also revealed that with discharge to the pit at frequent intervals, the water level and TDS values in the aquifer around the pit would remain high.

The contour maps of the groundwater head, depth to water and salt concentration over the model area also confirmed that while the head values quickly restored very near to the pre-discharge situation, once the discharge to the pit was stopped, the salt concentration in the groundwater persisted for a long time under the frequent recharge discharge condition. As suggested by the model, due to the infiltration from the pits, the head values during the discharge 
periods should have often exceeded the ground surface elevation directly below the pit and in the immediate vicinity, causing breakthrough of water on the surface. Visual inspection confirmed this to have happened several times in the past.

\section{Conclusions}

Analysis of available data and numerical modeling results suggests that:

1. The recharge pit is located within two kilometers of the Umm Al-Aish freshwater body (TDS $\leq 2000 \mathrm{mg} / \mathrm{l}$ ) and rests over an area where groundwater is brackish in nature (TDS $4500-6000 \mathrm{mg} / \mathrm{l}$ ) that can be used for irrigation and other commercial requirements.

2. The pit is located on the down gradient side of the freshwater body of Umm Al-Aish depression and because of its location, unless there is a reversal of gradient either due to the prolonged and high volume withdrawal from the freshwater body or high rate of recharge from the pit over a long time or both, threat of the freshwater body being contaminated by the leaked fluid from the pit is not high.

3. Due to the variations in the conditions of the floor of the pit and possible non-uniform deposition of heavy oil and sludge on the bottom, the leakage rate is non-uniformly distributed over the base of the pit.

4. The groundwater mound has reached a height of about $27 \mathrm{~m}$ in the vicinity of the pit and its base extends over a radius of about $0.5-1 \mathrm{~km}$ around the pit. The current TDS of the water body in the mound is $10,000 \mathrm{mg} / \mathrm{l}$ to $\geq 150,000 \mathrm{mg} / \mathrm{l}$ ) where the original water quality in the area was in the range of $4500-6000 \mathrm{mg} / \mathrm{l}$.

5. The mound will dissipate soon once the discharge to the pit, and hence recharge to the groundwater, is discontinued. A lowering of the height of the water table at the center of the saline plume may be discerned at this stage due to the salinity effect.

6. After complete stoppage of disposal of fluids to the pit, the contaminated plume will move to the east with time following the prevailing hydraulic gradient. Concurrently, density (and hence, salinity) stratification will take place within the aquifer, thus improving the water quality close to the water table, though complete restoration of the water quality to its original condition may not be expected in the near future.

\section{Recommendations}

The Sabriya pit is also within two kilometers of the Umm Al-Aish freshwater body. Unfortunately, this resource has already been contaminated by petroleum hydrocarbon released from the oil wells damaged by the Iraqi army during the 1991 gulf war and by seawater used during the subsequent firefighting effort. The pit is an additional source of possible contamination of both the freshwater body and the useful brackish water $(2,000-10,000 \mathrm{mg} / \mathrm{l})$ that occurs in the area. 
At least another monitoring well should be drilled between the pit and the Umm Al-Aish freshwater body to monitor any advance of the pollution plume from the pit to the freshwater reserve. Additionally, two to three monitoring wells may be drilled within a distance of one kilometer to the southeast of the pit where the pollution plume may extend as revealed by numerical modeling. Regular monitoring of these wells, including the four wells drilled around the pit during the current study, will provide more information on the movement and fate of the pollutants released from the pit and help in taking both preventive and remedial measures for protection of the vulnerable water resources of this area in time. It is recommended to stop the discharge of the oil field brines and other methods of disposal (e.g., injection into deep aquifers, remediation of the liquids through advanced zero-discharge techniques and others) should be considered.

\section{Acknowledgements}

The authors would like to express their gratitude to the Kuwait Oil Company (KOC) for funding the project and the team members of Research and Technology Group of KOC for assisting in the execution of the project. The constant support and encouragement of the management of Kuwait Institute for Scientific Research (KISR) are gratefully acknowledged. The authors would also like to express their thanks to the contributors of the project for their efforts in the preparation of this paper.

\section{References}

[1] Al-Hubail, J. and El-Dash, K., Managing disposal of water produced with petroleum in Kuwait. Journal of Environmental Management 79:43-50, 2006.

[2] Al-Kandari, A. and Rochford, D., Enhancing produced water quality in Kuwait Oil Company. Society of Petroleum Engineers, Annual Technical Conference and Exhibition, San Antonio, Texas, 5-8 October, 1997.

[3] Al-Yaqout, A., Koushki, P. and Hamoda, M., Public opinion and siting solid waste landfills in Kuwait. Resources, Conservation and Recycling 35(4):215-227, 2002.

[4] Koushki, P., Al-Duaij, O. and Al-Qimlass, W., Assessment of municipal solid waste collection and transportation in Kuwait. Kuwait Institute for Scientific Research, KISR Report No. 98-14-01, Kuwait, 2000.

[5] Alvillar, S. and Hahn, R., Risk-based assessment of a former oil field brine disposal pit. Proceedings of Air \& Waste Management Association's Annual Meeting \& Exhibition, Ontario, Canada. 11 p, 1997.

[6] Herkelrath, W., Kharaka, Y., Thordsen, J. and Abbott, M., Hydrology and subsurface transport of oil-field brine at the U.S Geological Survey OSPER site "A", Osage County, Oklahoma. Applied Geochemistry 22(10):21552163, 2007. 
[7] Kharaka, Y., Kakurous, E., Thordsen, J., Ambats, G. and Abbott, M., Fate and groundwater impacts of produced water releases at OSPER "B" Site, Osage County, Oklahoma. Applied Geochemistry 22(10):2164-2176, 2007.

[8] Pettyjohn, W., Monitoring cyclic fluctuations in groundwater quality. Ground Water 14(6):472-480, 1976.

[9] Uliana, M., Identifying the source of saline groundwater contamination using geochemical data and modeling. Environmental and Engineering Geoscience 11(2): 107-123, 2005.

[10] Ustera, H., Torres, C. and Fasola, M., Tracing groundwater pollution in the oil industry: myths and reality. In Proceedings of the SPE Latin American and Caribbean Petroleum Engineering Conference 3:1747-1751, 2007.

[11] USEPA., Field Methods Compendium (FRC) draft. United States Environmental Protection Agency. Office of Emergency and Remedial Response, Hazardous Site Evaluation Division, Analytical Operation Branch, Washington DC, USA, 1996.

[12] Guo, W. and Langevin, C. D., Users' Guide to SEAWAT: A computer program for simulation of three-dimensional variable-density ground-water flow. Open-File Report 01-434, United States Geological Survey, Tallahassee, Fl 32301, 2002. 